\title{
THE INTERNATIONAL ASPECTS OF RECIPROCITY ${ }^{\mathrm{I}}$
}

President Taft in his message to Congress of January 26, I9I I, states with the utmost cogency the general reasons which call for a closer commercial union between the United States and Canada. His exposition of the broad and statesmanlike considerations which should control the action of the two countries in this matter leaves little to be added. The technical effects of given changes in duty have been fully treated by competent authorities. It seems to me that the advantages to both countries certain to flow from the operation of the agreement are of so evident and considerable a nature as to make the desirability of its adoption unmistakable. I think it should be passed by the Senate without further delay, and that when it has been so adopted it will constitute one of the most creditable acts of the present administration. I believe in the agreement not because it is perfect or even satisfactory in its scope, but because it is a step toward the establishment of those equitable trade relations with Canada which can be reached only by a very marked reduction, if not actual abolition, of tariff restrictions upon the mutual interchange of commodities.

There is another aspect of the Canadian agreement, however, in which it constitutes a striking innovation upon past and present commercial policy, and which suggests the acceptance of a new attitude toward foreign countries more in harmony with existing conditions than the exclusive international position heretofore accepted by the United States. This, to my mind, transcends all other considerations in favor of reciprocity. The reciprocity agreement, if adopted, will without doubt be an important step toward the revision of our system of tariff treaties.

The international tariff position of the United States is today dependent upon two important factors: (I) the most-favorednation clause in our commercial treaties; (2) the present maxi-

${ }^{x}$ A paper read before the Western Economic Society, June 3, I9II. 
mum and minimum tariff provision of the Payne-Aldrich Act. If we add to the problem a new factor, (3) the reciprocity provision now proposed with Canada, how will it affect the operation of the other two elements?

The position of the United States as respects the mostfavored-nation clause is the product of a long period of development and is now absolutely anomalous. Early commercial treaties were arranged by European nations in strict accordance with the idea that every concession granted by one country to any other should be given only in exchange for similar concessions in return. In other words, the negotiation of commercial treaties was a sort of bargaining process in which a foreign nation might be overreached by its antagonist. The object to be kept in mind by either party was the arrangement of an agreement as favorable to it as circumstances, and the relative acuteness of the other, would allow. It is evident that, supposing two nations, $\mathrm{A}$ and $\mathrm{B}$, to have signed a commercial treaty granting certain privileges by mutual agreement, B might be at a considerable advantage with respect to a third nation, $\mathrm{C}$, in competing for the trade of A. If, subsequently, an agreement should be entered into between $\mathrm{A}$ and $\mathrm{C}$, whereby more elaborate concessions were allowed $\mathrm{C}$ than those which had been gained by $B$, it might turn out that $B$ would not merely be outstripped by $\mathrm{C}$ in the competition, but would even be worse off than would have been the case had no treaty been originally negotiated with A. It was this situation which led to the development of the most-favored-nation clause. Under it, states sought to obtain guarantees that in case future commercial concessions should be offered to their competitors, they themselves would, ipso facto, enjoy the same concessions. Thus, if the two nations, $\mathrm{A}$ and $\mathrm{B}$, had entered into a commercial agreement in which the mostfavored-nation stipulation has been incorporated, and if there should be any subsequent treaty between $\mathrm{A}$ and $\mathrm{C}$ in which larger concessions were granted, $\mathrm{C}$ would, by the nature of the case, extend those concessions also to B. Now, it is clear that the interpretation to be placed upon the clause might be such as to extend those concessions to B only in case B should pay for 
them by the same return concessions granted by $\mathrm{C}$, or should simply be permitted to enjoy them without any further payment than that already arranged for in the original A and B treaty.

Writers on international law distinguish several different forms of the "most-favored-nation clause." They enumerate more particularly the so-called "simply reciprocal form" and the so-called "imperative and unconditional form." In the first, "where reciprocity is the foundation of every clause in the treaty dealing with a subject of commerce and navigation, the inference points to reciprocity as the foundation for the general covering clause which is to supply omissions and prevent future unfavorable discrimination." Under the other interpretation, the commercial favors are granted to all countries under the mostfavored-nation clause "immediately and without condition"; in other words, without compensating privileges offered in return. It is easy to see why nations like Great Britain, which have adopted free trade as their policy and which have, as a matter of fact, nothing to offer in return for a reduction of duties, are disposed to insist strenuously upon this second interpretation.

The "simply reciprocal form" of the most-favored-nation clause is, of course, the one to which the United States has consistently held. It has, from the beginning, adhered rigidly to the view that trade concessions offered by it to some other country need not become common to a third country with which we have no treaty relations involving the most-favored-nation clause, unless that third nation should meet us on our own ground by granting the same favors that we secured at the hands of the other nations with which we had entered into treaty relations. In the treaty negotiated between the United States and France, February 6, I 778 , the following words occur:

The most Christian King and the United States engage mutually not to grant any particular favor to other nations in respect to commerce and navigation which shall not immediately become common to the other party, who shall enjoy the same favor freely, if the concession was freely made or on allowing the same compensation if the concession was conditional.

In Art. IX of the treaty with Prussia, in I828, and in Art. IX of the treaty with Austria, in I829, occur the words: 
If either party shall hereafter grant to any other nation any particular favor in navigation or commerce, it shall immediately become common to the other party, freely, where it is freely granted to such other nation, or on yielding the same compensation, when the grant is conditional.

On the other hand, European diplomacy has developed the most-favored-nation clause along a different line, following the second of the two interpretations already referred to. As things now stand, most European countries admit that nations which have granted to other nations the benefits of the most-favorednation clause have guaranteed to the latter that their commercial relations shall not be less favorable with the guarantors than shall those of any other country. In other words, new and more extensive trade concessions granted by country A to $\mathrm{C}$, a third nation, are, ipso facto, extended to $\mathrm{B}$, a second nation, with which it has originally entered into commercial relations, while $\mathrm{B}$ obtains these advantages without compensation even though they may have been paid for very heavily by C. This, of course, is a marked reversal of the original interpretation given to the "most-favored-nation clause" during the eighteenth and first half of the nineteenth century. It is a most important point to bear in mind, in studying the development of reciprocity as a policy, for it will readily be seen that the adoption of the European interpretation of the most-favored-nation clause implies either the giving up of all commercial treaties, or else the conscious recognition of tariff reduction as a system to be regularly applied whenever granted in an individual case. Reciprocity, when limited to isolated instances, becomes nothing more than a process of international bargaining, which may or may not be undertaken, as circumstances of the particular case seem to indicate.

It is apparent that the United States in maintaining its own interpretation of this clause, reserving the right to grant tariff concessions only in return for certain other concessions and the right to decide whether concessions offered by other countries are equivalent to those obtained from any particular country, occupies a peculiar and anomalous position as compared with a group of nations adhering to a different interpretation and grant- 
ing to us the advantages of the clause, which we, however, deny to them. All of this has led to exceedingly unfavorable comment on the part of European countries, which regard our attitude on the subject of the most-favored-nation clause as characteristically selfish.

We can better understand the application of this interpretation of the most-favored-nation clause by considering the precise details of the instructions given to our diplomatic representatives on some critical occasions. These are fully set forth in Foreign Relations, but Secretary Knox has lately sent to the Senate a useful compilation of precedents from which a few may be chosen.

The treaty of April 30, I803, for the cession of Louisiana provided, in Art. VIII, that "the ships of France shall be treated upon the footing of the most-favored nations" in the ports of the ceded territory. By act of Congress of March 3, I8I5, the vessels of foreign countries were exempted from discriminating tonnage duties in the ports of the United States, provided that such countries granted reciprocal treatment to American ships in their ports. Great Britain took advantage of this offer of reciprocity and removed her discriminating duties against American shipping. France, however, took no action, with the result that French vessels continued to pay discriminating duties when entering United States ports, while British vessels were exempt. The French minister, in a note to the Department of State, under date of December I5, I8I7, claimed that the exemption granted to British shipping should likewise be extended to French shipping by virtue of Art. VIII of the treaty of I803.

Secretary of State John Quincy Adams, in his reply of December 23, I8I7 (American State Papers, For. Rel., V, I 52-53), defined the position of the United States as follows:

The undersigned is instructed to say that the vessels of France are treated, in the ports of Louisiana, upon the footing of the most-favored nation, and that neither the English nor any other foreign nation enjoys any gratuitous advantage there which is not equally enjoyed by France. But English vessels, by virtue of a conditional compact, are admitted into the ports of the United States, including those of Louisiana, upon payment of 
the same duties as the vessels of the United States. The condition upon which they enjoy this advantage is, that the vessels of the United States shall be admitted into the ports of Great Britain upon payment of the same duties as are there paid by British vessels.

The eighth article of the treaty of cession stipulates that the ships of France shall be treated upon the footing of the most-favored nations in the ports of the ceded territory; but it does not say, and cannot be understood to mean, that France should enjoy as a free gift that which is conceded to other nations as a full equivalent.

It is obvious that if French vessels should be admitted into ports of Louisiana upon the payment of the same duties as the vessels of the United States, they would be treated, not upon the footing of the most-favored nation, according to the article in question, but upon a footing more favored than any other nation; since other nations, with the exception of England, pay higher tonnage duties, and the exemption of English vessels is not a free gift, but a purchase at a fair and equal price.

It is true that the terms of the eighth article are positive and unconditional; but it will readily be perceived that the condition, though not expressed in the article, is inherent in the advantage claimed under it. If British vessels enjoyed, in the ports of Louisiana, any gratuitous favor, undoubtedly French vessels would, by the terms of the article, be entitled to the same.

During the negotiations between the governments of the United States and Great Britain which resulted in our reciprocity treaty of 1854 with Canada, Mr. Crampton, the British chargé d'affaires at Washington, under instructions from his government, wrote to Secretary of State Clayton, as follows :

It has been objected that, if certain agricultural articles (more particularly wheat), the production of Canada, were to be admitted free of duty into the United States, under a convention with the British government for a reciprocal free trade between that province and the United States in such productions, the like productions of other nations having "reciprocity treaties" of commerce with the United States must be admitted on the same terms.

To this it may be replied that no nation could claim for itself an advantage under a convention between Great Britain and the United States, which Great Britain herself had not obtained under that convention. Had any other nation a colony similarly situated, she might then be borne out in claiming that such colony should be equally favored; otherwise not.

The reciprocity convention concluded between the United States and the Hawaiian Islands on January 30 , I875 (effective 
September 9, I876), provided, in Art. IV, that the Hawaiian Islands should not, so long as the treaty remained in force, "make any treaty by which any other nation shall obtain the same privileges, relative to the admission of any article free of duty, hereby secured to the United States."

Invoking the most-favored-nation clause in Art. IV of her treaty with the Hawaiian Islands, Great Britain demanded that the latter should extend, gratuitously, to the United Kingdom the tariff concessions granted in reciprocity to the United States.

The position of the United States government in this matter was set forth in a note from Mr. Comly, American minister at Honolulu, dated July I, I878, to the Hawaiian foreign office, reading in part as follows (For. Rel., I878, 404):

No treaty in existence at the time this compact was entered into secured to any other nation the privileges as to the admission of certain articles free of duty, which have been guaranteed to the United States by this treaty. These privileges were secured, not through any general treaty rights or stipulations, but by giving certain valuable considerations in a special treaty of reciprocal covenants. The concession of these privileges to the United States cannot, therefore, form any just basis for a claim to like privileges by any other nation, under the parity clause of any ordinary form of treaty. The uttermost that might be conceded under such parity clause would be the claim to purchase the same immunities through special treaty, upon like terms with those agreed upon between the United States and the Hawaiian Islands.

Sec. 608 of the United States tariff act of I894 placed salt upon the free list, but provided that if salt should be imported from any country that imposed a duty upon salt imported from the United States there should be levied on the salt of such country the rate of duty existing prior to the passage of the tariff act. Notwithstanding that American salt was dutiable on importation into Germany, the German government demanded free entry of German salt into the United States by virtue of the most-favored-nation clauses (Arts. V and IX) of the treaty of 1828 between the United States and Prussia. The question having been submitted to Attorney-General Olney, he gave an exhaustive opinion, under date of November I3, I894, in which he said: 
The most-favored-nation clauses of our treaties with foreign powers have from the foundation of the government been invariably construed both as not forbidding any internal regulations necessary for the protection of our home industries and as permitting commercial concessions to a country which are not gratuitous, but are in return for equivalent concessions, and to which no other country is entitled except upon rendering the same equivalents. Thus, Mr. Jefferson, when Secretary of State in I792, said of treaties exchanging the rights of the most-favored nation that "they leave each party free to make what internal regulations they please, and to give what preference they find expedient to native merchants, vessels, and productions." In I817, Mr. John Quincy Adams, acting in the same official capacity, took the ground that the "most-favored-nation clause only covered gratuitous favors and did not touch concessions for equivalents expressed or implied." $\mathrm{Mr}$. Clay, Mr. Livingston, Mr. Evarts, and Mr. Bayard, when at the head of the Department of State, have each given official expression to the same view. It has also received the sanction of the Supreme Court in more than one well-considered decision.

In I898, during the reciprocity negotiations between the United States and the Argentine Republic, under the provisions of section 4 of the United States tariff act of July 31, I897, Mr. Buchanan, the American minister at Buenos Ayres, reported to Secretary of State Sherman that the Argentine government was apparently deterred from entering into a treaty of reciprocity with the United States because it assumed that it would be compelled to extend any tariff concessions which it might make in such a treaty with the United States to European countries with which the Argentine Republic had commercial treaties provided for most-favored-nation treatment.

In reply to this dispatch Secretary of State Sherman instructed Minister Buchanan, under date of January I I, I898 (Ms. Inst. Arg. Rep., XVII, 306), as follows in regard to the United States' construction of the most-favored-nation clause:

It is clearly evident that the object sought in all the varying forms of expression is equality of international treatment, protection against the wilful preference of the commercial interests of one nation over another, but the allowance of the same privileges and same sacrifice of revenue duties to a nation which makes no compensation that has been conceded to another nation for an adequate compensation, instead of maintaining destroys that equality of market privileges which the most-favored-nation clause was intended to secure. It concedes for nothing to one friendly nation what the other gets 
only for a price. It would thus become the source of international inequality and provoke international hostility. The neighborhood of nations, their border interests, their differences of climate, soil, and production, their respective capacity for manufacture, their widely different demands for consumption, the magnitude of the reciprocal markets, are as many conditions which require special treatment. No general tariff can satisfy such demands. It would require a certainty of language which excludes the possibility of doubt to justify the opinion that the government of any commercial nation had annulled its natural right to meet these special conditions by compensatory concessions, or held the right only on condition of extending the same to a nation which had no compensation to offer. The fact that such concessions if made would inevitably inure to the equal benefit of a third competitor would often destroy the motive for, as well as the value of, such reciprocal concessions.

But instead of such certainty of expression, one of the articles in each of the treaties referred to contains a distinct recognition that special and compensatory commercial arrangements may be made, notwithstanding the most-favored-nation clause; and provided that in such cases the favors granted shall be enjoyed by the party claiming favored-nation treatment, gratuitously if so granted, or for equivalent compensation if granted for a price.

What will be an equivalent compensation is to be honorably determined by the governments concerned. So many considerations have necessarily entered into such special concessionary agreements that no universal rule can be applied. The price has often been special privileges in the market of the other for certain manufactures or products of the contracting country; but it may also be a port, a bay, or an island, or a protectorate, as well as an expanded market, or a privileged export trade. It may be anything within the range of the treaty-making power.

It is not to be supposed that a right of such importance in many national emergencies has been abandoned by the Argentine Republic, or that it is only held on condition of the repeated and gratuitous payment to other countries of the same consideration stipulated in reciprocity. The right of the other nations to enjoy the same special concessions depends on their ability to offer an equivalent compensation. When they do this, the favorednation clause is rightfully invoked.

Hitherto the United States has stoutly maintained its claim that we cannot properly be called upon to make common even to those nations with which we have a most-favored-nation clause the advantages accorded to any one unless others which desire the same advantages are willing to extend equivalent concessions. We have, however, consistently taken the view that 
where other nations were thus willing to grant equivalent concessions they might receive the same reductions we had accorded to any one of their competitors. This was a position which, though out of harmony with the European interpretation of the most-favored-nation clause, has until recently been at least tenable.

Whatever may be thought of this position regarding the most-favored-nation clause in commercial treaties there was at least a basis for considering it a self-respecting and self-consistent position on the tariff question. But the Payne-Aldrich Act introduced a new element of difficulty by including the socalled maximum and minimum provision. This was found in sec. 2 and was as follows:

That from and after the thirty-first day of March, nineteen hundred and ten, except as otherwise specially provided for in this section, there shall be levied, collected, and paid on all articles when imported from any foreign country into the United States or into any of its possessions (except the Philippine Islands and the Islands of Guam and Tutuila), the rates of duty prescribed by the schedules and paragraphs of the dutiable list of section one of this Act, and in addition thereto twenty-five per centum ad valorem; which rates shall constitute the maximum tariff of the United States,

Provided, That whenever, after the thirty-first day of March, nineteen hundred and ten, and so long thereafter as the President shall be satisfied, in view of the character of the concessions granted by the minimum tariff of the United States, that the government of any foreign country imposes no terms or restrictions, either in the way of tariff rates or provisions, trade, or other regulations, charges, exactions, or in any other manner, directly or indirectly, upon the importation into or sale in such foreign country of any agricultural, manufactured, or other product of the United States, which unduly discriminates against the United States or the products thereof, and that such foreign country pays no export bounty or imposes no export duty or prohibition which unduly discriminates against the United States or the products thereof, and that such foreign country accords to the agricultural, manufactured, or other products of the United States treatment which is reciprocal and equivalent, thereupon and thereafter, upon proclamation to this effect by the President of the United States, all articles when imported into the United States, or any of its possessions (except the Philippine Islands and the islands of Guam and Tutuila), from such foreign country shall, except as otherwise herein provided, be admitted under the terms of the minimum tariff of the United States as prescribed by section one of this Act. 
By virtue of this provision we promptly represented to all foreign countries that unless they could consent to give us their lowest tariff rates we should be obliged to impose upon them the maximum duties threatened in the law. With most countries little or no difficulty was experienced. But in the case of Germany, France, and Canada the situation was quite different. Although for some time an official statement of the results of these negotiations was withheld, it is now published as H.R., sec. 956, 6rst Cong., 2d sess.

The German government withheld from numerous classes of imports from the United States the benefit of its conventional or minimum tariff rates. These conventional rates represented reductions of duty made by Germany as concessions to various governments of Europe in return for equivalent concessions made by them in reciprocity treaties, the mutual benefits of which were given wide application through the operation of the most-favored-nation clause as construed by European governments. The Department of State had found it impossible, previous to the passage of the Act of August 5, 1909, to obtain for American commerce complete equality of tariff treatment in Germany. The negotiations resulted in action by Germany granting to the United States her full conventional tariff rates in return for the minimum tariff of the United States, this being an exchange of minimum for minimum. The United States was thus placed on exactly the same terms as all other countries to which Germany had granted her conventional tariff in pursuance of treaty stipulations.

The tariff conditions affecting American commerce in France, particularly as regards finished products of manufacture, had been unfavorable. Under the commercial agreements of 1898 and 1908 providing for limited reciprocity, the benefit of the minimum rates on 25 numbers of the French tariff had been granted to the United States. All leading commercial nations competing with the United States in the markets of France had the benefit of the complete French minimum tariff. During the interval between November I, I909, and March 3I, I9IO, 
the French government applied its complete maximum tariff rates to all dutiable importations from the United States.

By the settlement with France, under which the minimum tariff of the United States was granted to that country, France granted the minimum tariff rates to the United States on about 80 numbers of the tariff where two rates existed. These cover manufactured articles, including agricultural and various other forms of implements, tools, and machinery. In addition, assurances were given as to the maintenance of many general tariff rates in the French schedule, the understanding being that if certain rates are lowered the United States shall be accorded such reduction.

The question requiring adjustment with Canada grew out of the Franco-Canadian treaty which was put in force between the two countries February I, I9Io. The Canadian tariff consists of three schedules-general, intermediate, and British preferential. The British preferential rates are extended only to the United Kingdom and to various British colonies. The intermediate rates are the minimum rates to all other countries. Under the terms of the Franco-Canadian treaty France was given a series of intermediate rates and in addition a small list of special rates applying to peculiarly French products. By the operation of the favored-nation treatment, the treaty rates were extended automatically to several countries besides France, some of whose products competed with the products of the United States in the Canadian market. This question was adjusted after a bitter struggle by the extension on the part of Canada of rates below the intermediate rates of the Canadian tariff to a very few exports of the United States.

A final word may be desirable by way of stating the present position of the United States under the most-favored-nation clause and the Payne-Aldrich Act. We have in force today treaties including the most-favored-nation clause with the following nations:

I. With the equivalence clause.-Argentine Republic, Austria-Hungary, Belgium, Bolivia, Colombia (New Granada), Costa Rica, Denmark, Hanseatic Republics, Haiti, Honduras, 
Italy, Japan, Liberia, Mecklenburg-Schwerin, Oldenburg, Paraguay, Prussia, Russia, Sweden and Norway, Tonga, Tripoli.

2. Without the equivalence clause,-China, Ethiopia (Abyssinia), Great Britain, Greece, Ottoman Empire, Persia, Servia.

3. Unilateral clause.-Egypt, Morocco, Siam.

With foreign countries we thus have arrangements guaranteeing us the lowest rates granted any other country at present except as already indicated: (I) with France; (2) with Canada; (3) with Germany. To these should be added the familiar tariff concession of 20 per cent made to Cuba and the arrangement for limited free trade with the Philippines, as well as an agreement with Brazil, whereby we receive a few special concessions.

If now a reciprocity arrangement with Canada shall be accepted, how will it affect this existing status?

It is evident that such an agreement will be tantamount to the establishment of a new set of minimum duties if the theory at bottom of our maximum and minimum provisions shall be held to continue in force. Under these circumstances what will be the necessary attitude of foreign countries?

I. They may demand that they be granted the benefits of the lower Canadian rates without any concessions in return. In so doing they would be demanding nothing more than we ourselves called for in our negotiations under the maximum and minimum provision. But in granting such a demand we should be violating the recognized and traditional reciprocity policy of the United States and the peculiar interpretation of the mostfavored-nation clause by which it has been accompanied.

2. Or they may assent to the interpretation of reciprocity and the most-favored-nation clause which is implied in the instructions of Secretary Sherman to Minister Buchanan in I 898 where he said, with reference to the claims of other governments to certain rights which we contemplated extending to the Argentine Republic, that:

The right of the other nations to enjoy the same special concessions depends on their ability to offer an equivalent compensation. When they do this, the favored-nation clause is rightfully invoked.

And again : 
What will be an equivalent compensation is to be honorably determined by the governments concerned.

But, should they adopt this point of view, they would indubitably retain the right to insist upon obtaining privileges equivalent to those granted Canada conditional upon offering similar privileges in exchange. For as Mr. Sherman says:

When they do this [offer an equivalent compensation] the favorednation clause is rightfully invoked.

And as Secretary Hay said to Ambassador White in I899 with reference to a claim of Germany to be treated in the same way as Switzerland by virtue of the most-favored-nation clause:

Nothing has been conceded to Switzerland which under like conditions would not have been given to Germany.

That the United States could, without a struggle, surrender its traditional interpretation of the most-favored-nation clause is hardly to be expected. The question would, therefore, remain whether the United States could refuse to open negotiations for the extension of reciprocity arrangements to other countries which might demand such arrangements. Should it so refuse, it must expect to see the present minimum-rate basis granted by foreign countries withdrawn. In fact, it may be expected that almost immediately upon the completion of the Canadian agreement Germany will withdraw from us certain of the minimum rates now enjoyed by the United States. Germany, it is well understood, has already made inquiries regarding the probable answer of the United States to a request for the extension of the lower rates of the Canadian agreement to her and is apparently prepared to carry her point to the logical extreme. The question of England's position has already been raised in Parliament and will also be pushed as opportunity favors. Such demands could not be refused, nor could we expect to secure much attention for the former threat that we shall apply our maximum tariff rates to countries which grant a special preference to others.

It is thus apparent that one of the most important aspects of the Canadian agreement is found in the fact that it is an important step toward free trade. The old reciprocity treaty with 
Canada did not operate in that direction for several reasons: it was terminated too early, before our commercial policy or that of European nations under the high tariff system had been well developed; it fell at a troubled time in national and world history when but little attention could be given to matters of trade and commerce; it affected a country which was then distinctly a dependency of England in the narrowest sense of the term; it antedated by many years the keen struggle for markets which is now in progress. But today the situation is quite different. We may expect that every step in our commercial policy will be closely watched by our rivals and colleagues in international trade. If it is true, as I have suggested, that reciprocity with Canada must be considered in the historical light and that what we shall do must be guided by our course in the past, we cannot escape the belief that this treaty will constitute a first and most important step away from the unsatisfactory conditions created under the Payne-Aldrich Act. It will necessitate our entering into similar agreements with all countries with which we expect to enjoy friendly trade relations. Refusal to grant concessions in exchange for similar concessions, as we had done with Canada, could only result in friction and international irritation of the pronounced kind and must necessarily subject this country to severe retaliation.

The most important aspect of the present agreement, therefore, is its general international aspect. It opens the way to an improvement of the present unsatisfactory conditions in trade, suggests a development toward less exclusiveness in the future, and affords a possibility of hopeful solution of many trying questions.

The Senate, having acted on this matter, must needs be constrained by the trade policy of other countries to act in others in the future. If the Canadian treaty be adopted, it may prove the first step in a broad tariff policy. It is the first step that costs most, and corresponding credit is due the man who has the courage to take it in the right direction.

\section{H. Parker Willis}

WaShington, D.C. 